\title{
PENGARUH ABSENSI FINGERPRINT TERHADAP PENINGKATAN DISIPLIN KERJA PEGAWAI DI KEMENTERIAN KOMUNIKASI DAN INFORMATIKA
}

\author{
Fahmi Kamal $^{1}$, Widi Winarso ${ }^{2}$, Wastam Wahyu Hidayat ${ }^{2}$ \\ Fakultas Ekonomi dan Bisnis, Universitas Bina Sarana Informatika ${ }^{1}$ \\ Program Studi Manajemen, Fakultas Ekonomi dan Bisnis, Universitas Bhayangkara Jakarta Raya, \\ Bekasi $^{2,3}$ \\ fahmi.fmk@bsi.ac.id ${ }^{1}$, widi.winarso@dsn.ubharajaya.ac.id ${ }^{2}$, \\ wastam.wahyu@dsn.ubharajaya.ac.id ${ }^{3}$ \\ Penulis untuk Korespondensi/E-mail: fahmi.fmk@bsi.ac.id
}

\begin{abstract}
Abstrak
Absensi fingerprint merupakan absensi yang memakai sidik jari manusia, dan sidik jari adalah identitas pribadi yang tidak mungkin ada yang menyamakannya. Sifat atau karakteristik yang dimiliki oleh sidik jari adalah parennial nature, yaitu guratan-guratan pada sidik jari manusia yang melekat seumur hidup. Lazimnya absensi dipakai pada setiap kehadiran dalam bekerja sehari - hari. Absensi fingerprint merupakan alat penggerak pegawai untuk hadir tepat waktu dan pulang kerja sesuai dengan waktu yang telah ditetapkan. Hal ini digunakan agar para pegawai dapat meningkatkan kedisiplinan dalam bekerja. Metode dalam penelitian ini adalah untuk mengetahui seberapa besar pengaruh absensi fingerprint terhadap peningkatan disiplin kerja pegawai yaitu dengan metode statistik SPSS versi 25. berupa Uji Koefisien Korelasi, Uji Koefisien Determinasi dan Uji Persamaan Regresi sehingga dapat diketahui tindakan dan pemecahannya. Berdasarkan olah data yang penulis lakukan hasil penelitian ini menunjukkan bahwa nilai Koefisiensi Korelasi sebesar 0,773 artinya absensi fingerprint yang diselenggarakan memiliki adanya hubungan yang positif dan kuat terhadap peningkatan disiplin kerja pegawai pada kementerian komunikasi dan informatika Jakarta, sedangkan hasil Koefisien Determinasi berkontribusi sebesar 59.7\% dan sisanya 40.3\% dimungkinkan oleh pengaruh dari faktor lainnya. Hasil Persamaan Regresi sebesar $\mathrm{Y}=-1,625+1,010 \mathrm{X}$ artinya setiap variable mendapatka penurunan 1 kali, sehingga dapat mengalami penurunan sebesar 1,010. Dengan demikian absensi fingerprint berpengaruh kuat terhadap peningkatan kedisiplinan kerja pegawai.
\end{abstract}

Kata Kunci : Absensi Fingerprint, Disiplin Kerja Pegawai.

\begin{abstract}
Fingerprint attendance is attendance that uses human fingerprints, and fingerprints are personal identities that cannot be equated. The nature or characteristics possessed by fingerprints is the parennial nature, which is the strokes on human fingerprints that are inherent for life. Usually, attendance is used for every attendance at work everyday. Fingerprint attendance is a tool to motivate employees to arrive on time and leave work according to the predetermined time. This is used so that employees can improve discipline at work. The method in this research is to find out how much influence the fingerprint attendance has on the improvement of employee work discipline by using the SPSS version 25 statistical method in the form of Correlation Coefficient Test, Determination Coefficient Test and Regression Equation Test so that the action and solution can be known. Based on the data processing by the authors, the results of this study indicate that the Correlation Coefficient value of 0.773 means that the fingerprint attendance that is held has a positive and strong relationship to the improvement of employee work discipline at the Ministry of Communication and Informatics Jakarta, while the results of the Coefficient of Determination contribute 59.7\% and the rest $40.3 \%$ is made possible by the influence of other factors. The result of the regression equation is $Y=-1,625+1,010$
\end{abstract}


$X$ means that each variable gets a decrease of 1 time, so that it can decrease by 1.010. Thus fingerprint attendance has a strong effect on improving employee work discipline.

Keywords: Fingerprint Attendance, Employee Work Discipline.

\section{PENDAHULUAN}

Satu komponen terpenting yang dapat diperhatikan dalam penegakan disiplin adalah masalah absensi kehadiran pegawai. Dalam perspektif masyarakat terdapat stigma negatif bahwa Pegawai Negeri Sipil atau Aparatur Sipil Negara (ASN) itu hanya datang saja dan mengabsen saja, sementara dalam perilaku kerjanya sehari-hari tidak seusai dengan kedisiplinannya. Sudah menjadi kebiasaan negatif bagi sebagian oknum ASN absensinya hanya dititipkan pada teman lain. Masalah titip-menitip absensi adalah hal yang sudah mengakar bagi masyarakat Indonesia. Hal tersebut wajib diselesaikan dalam penegakan disiplin dalam lingkungan instansi pemerintahan. Kedepannya diharapkan dengan adanya absensi sidik jari (fingerprint) tidak ada seorang pun yang menitip absen.

Absensi menjadi sistem yang terkendali pada suatu instansi yang digunakan untuk mencatat dan mengevaluasi kehadiran setiap anggotanya di instansi tersebut. Sistem absensi melaporkan hasil catatan identitas pegawai dan waktu keluar masuknya semua pegawai. Sistem ini meilikii kemampuan dalam memberikan laporan yang akurat pada pimpinan atau manajer. Oleh karena itu, kebanyakan perusahaan baik swasta maupun pemerintah memanfaatkan daftar kehadiran pegawai untuk menentukan insentif atau tunjangan kepada para pegawainya.

Ada beberapa cara dalam mencatat kehadiran pegawai disuatu instansi, yaitu manual dan menggunakan absensi sidik jari (fingerprint). Hal ini terjadi karena kemungkinan penitipan absensi lebih dapat dicegah dari pada yang menggunakan absensi manual. Sistem absensi Kementerian Komunikasi dan Informatika Jakarta saat ini menggunakan absensi sidik jari (fingerprint). Dikarenakan tingkat absensi pegawai dapat dikontrol dan diawasi secara akurat guna memudahkan dalam pemberian sanksi disiplin bagi pegawai yang tidak melaksanakan maupun untuk melihat tingkat kedisiplinan para pegawainya.

\section{Rumusan Masalah}

Berdasarkan uraian diatas maka dapat dirumuskan masalah penulisan sebagai berikut:
1. Apakah ada pengaruh absensi fingerprint dengan disiplin kerja pegawai Pada Kementerian Komunikasi Dan Informatika?

2. Seberapa besar pengaruh absensi fingerprint dengan disiplin kerja pegawai?

\section{Tujuan Penulisan}

Tujuan penulisan ini adalah untuk mengetahui dan menjelaskan secara ilmiah pengaruh absensi fingerprint dengan disiplin kerja pegawai Pada Kementerian Komunikasi Dan Informatika. Sesuai dengan maksud penulisan tersebut, maka tujuan penulisan ini adalah:

1. Untuk mengetahui dan menjelaskan kuatnya pengaruh absensi fingerprint terhadap disiplin kerja pada Kementerian Komunikasi Dan Informatika.

2. Untuk mengetahui seberapa besar pengaruh absensi fingerprint terhadap disiplin kerja pada Kementerian Komunikasi Dan Informatika.

\section{TINJAUAN PUSTAKA}

\section{Pengertian Sidik Jari}

Menurut Kristin: "Sidik Jari merupakan identitas pribadi yang tidak mungkin ada yang menyamainya. Sifat-sifat atau karakteristik yang dimiliki oleh sidik jari adalah parennial nature yaitu guratan- guratan pada sidik jari yang melekat pada manusia seumur hidup, immutability yang berarti bahwa sidik jari seseorang tak akan pernah berubah kecuali sebuah kondisi yaitu terjadi kecelakaan yang serius sehingga mengubah pola sidik jari yang ada dan individuality yang berarti keunikan sidik jari merupakan originalitas pemiliknya yang tak mungkin sama dengan siapapun di muka bumi ini sekali pun pada seorang yang kembar identik." (Kristin, 2016).

\section{Absensi Fingerprint}

Absensi adalah sebuah kegiatan pengambilan data guna mengetahui jumlah kehadiran pada suatu acara. Dan perusahaan menggunakan sistem absensi untuk mengetahui kehadiran dan ketidakhadiran karyawan. 
Salah satu sistem absensi yang banyak digunakan di perusahaan adalah sistem absensi fingerprint atau sidik jari. Sidik jari merupakan garis yang terdapat pada guratan garis jari tangan yang sering digunakan untuk keperluan pengenalan identitas seseorang. Sidik jari manusia sedemikian uniknya sehingga tidak ada seorangpun yang memiliki sidik jari yang identik dengan orang lain.

Menurut Samiaji dalam (Erlangga, 2017), metode absensi yang lebih modern adalah dengan menggunakan presensi sidik jari. Pada metode ini pegawai harus memindai jari untuk presensi. Secara otomatis mesin presensi ini memasukan data jam masuk dan pulang ke dalam komputer. Hasilnya catatan jam k erja yang akurat dan siap diolah dengan aplikasi. Presensi tidak dapat dititipkan dan memperkecil kemungkinan kesalahan. Pendapat lain dikemukakan oleh Noersasongko \& Pulung dalam (Kristin,2016) mengenai fingerprint sebagai salahsatu bentuk biometric yang dilakukan untuk mengidentifikasi manusia. Scanner jenis ini membaca berdasarkan pola jari manusia. Terdapat tiga pola dasar sidik jari yaitu, arch, loop dan whorl. Scanner akan mengirim gambar sidik jari manusia dengan salah satu dari tiga pola tersebut untuk dianalisis oleh komputer.

Sedangkan menurut Moch. Tofik dalam (Setiawan \& Yulianti, 2018) bahwa "fingerprint adalah teknologi yang menunjang untuk keperluan absensi, yang di dalamnya mencangkup pemasukan, penyimpanan data jam masuk dan jam pulang, serta memproses data tersebut menjadi sebuah laporan yang nantinya dapat dipergunakan untuk pengambilan kebijakankebijakan yang dilakukan oleh pimpinan. Alat ini dilengkapi dengan software untuk melakukan perekaman atas transaksi yang terjadi”.

Mesin absensi sidik jari (fingerprint) merupakan Sistem Informasi Manajemen yang mengandung elemen-elemen fisik sebagaimana diungkapkan oleh Davis dalam (Hasiolan, Fathoni : 2016) bahwa unsur-unsur Sistem Informasi Manajemen adalah sebagai berikut:

1. Perangkat keras komputer, terdiri atas komputer (pusat pengolahan, unit masukan/keluaran, unit penyimpanan, file, dan peralatan penyimpanan data).

2. Database (data yang tersimpan dalam media penyimpanan komputer).

3. Prosedur, komponen fisik karena prosedur disediakan dalam bentuk fisik, seperti buku panduan dan instruksi.
4. Personalia pengoperasian, seperti operator komputer, analisis sistem pembuatan program, personalia penyimpanan data dan pimpinan sistem informasi.

\section{Mekanisme Fingerprint}

Mekanisme Fingerprint dalam absensi merupakan sebuah sistem yang ada di suatu instansi yang digunakan untuk mencatat daftar kehadiran setiap anggota instansi tersebut. Sistem absensi mencatat identitas anggota instansi dan waktu keluar-masuk anggotanya. Sistem absensi juga mempunyai kemampuan untuk memberikan laporan yang akurat.

Menurut Heriawanto dalam (Safudin, 2017), pelaksanaan pengisian daftar hadir atau absensi secara manual (hanya berupa buku daftar hadir), akan menjadikan penghambat bagi instansi untuk memantau kedisiplinan pegawai dalam hal ketepatan waktu kedatangan dan jam Pulang pegawai setiap hari. Hal tersebut dikhawatirkan akan membuat Komitmen pegawai terhadap pekerjaan dan instansi menjadi berkurang.

Berkurangnya komitmen dalam bekerja akan berdampak pada motivasi dan kinerja pegawai yang semakin menurun. Cahyana dalam (Kristin, 2016), menyatakan bahwa pencatatan absensi pegawai Merupakan salah satu faktor penting dalam pengelolaan sumber daya manusia. Informasi yang mendalam dan terperinci mengenai kehadiran seorang pegawai dapat menentukan prestasi kerja seseorang, gaji/upah, produktivitas, dan kemajuan instansi atau lembaga secara umum.

Menurut Ifa $\mathrm{H}$. Misbach dalam (Dalle \& Bakeri, 2019) sidik jari merupakan struktur genetika dalam bentuk rangka yang sangat detail dan tanda yang melekat pada diri manusia yang tidak dapat dihapus atau diubah. Sidik jari ibarat barcode diri manusia yang menandakan tidak ada pribadi yang sama. Sidik jari bersifat spesifik, permanen serta mudah diklasifikasikan.

Sedangkan menurut Suyadi dalam (Dalle \& Bakeri, 2019) sidik jari adalah kulit pada telapak tangan atau kaki yang tertutupi garis timbul kecil yang disebut rabung gesekan. Finger print (sidik jari) mempunyai tingkat akurasi mencapai 90 95\% dan tidak dipengaruhi oleh kondisi apapun bahkan tidak berubah sepanjang hayat.

\section{Prosedur Fingerprint}

Menurut Muhammad Ali dalam (Hasiolan et al., 2016) "Prosedur adalah tata cara kerja atau cara menjalankan suatu pekerjaan". Menurut Amin Widjaja dalam (Setiawan \& Yulianti, 2018) 
Prosedur adalah sekumpulan bagian yang saling berkaitan misalnya : orang, jaringan gudang yang harus dilayani dengan cara yang tertentu oleh sejumlah pabrik dan pada gilirannya akan mengirimkan pelanggan menurut proses tertentu.

Berdasarkan pendapat beberapa ahli di atas maka dapat disimpulkan yang dimaksud dengan prosedur adalah suatu tata cara kerja atau kegiatan untuk menyelesaikan pekerjaan dengan urutan waktu dan memiliki pola kerja yang tetap yang telah ditentukan.

\section{Disiplin Kerja}

\section{Pengertian Disiplin Kerja}

Menurut Moenir dalam Ardiansyah dalam (Sutrisno, 2017) disiplin adalah suatu bentuk ketaatan terhadap aturan, baik tertulis maupun tidak tertulis, yang telah ditetapkan. Sedangkan menurut Helmi dalam (Erlangga, 2017) di dalam jurnal penelitiannya menjelaskan bahwa "disiplin kerja merupakan suatu sikap dan perilaku yang berniat untuk mentaati segala peraturan organisasi yang didasarkan atas kesadaran sendiri untuk menyesuaikan dengan peraturan organisasi.

Menurut Terry dalam (Safudin, 2017) disiplin merupakan alat penggerak karyawan. Agar tiap pekerjaan dapat berjalan dengan lancer, maka harus diusahakan agar ada disiplin yang baik. Terry kurang setuju jika disiplin hanya dihubungkan dengan hal-hal yang kurang menyenangkan (hukuman), karena sebenarnya hukuman merupakan alat paling akhir untuk menegakkan disiplin.

\section{Faktor Yang Mempengaruhi Disiplin Kerja}

Menurut Singodimedjo dalam (Sutrisno, 2017); faktor yang mempengaruhi disiplin pegawai adalah:

1. Besar kecilnya pemberian kompensasi.

Besar kecilnya kompensasi dapat mempengaruhi tegaknya disiplin. Para karyawan akan mematuhi segala peraturan yang berlaku, bila ia merasa mendapat jaminan balas jasa yang setimpal dengan jerih payahnya yang telah dikontribusikan bagi perusahaan. Bila ia menerima kompensasi yang memadai, mereka akan dapat bekerja tenang dan tekun, serta selalu berusaha bekerja dengan sebaik-baiknya. Akan tetapi, bila ia merasa kompensasi yang diterimanya jauh dari memadai, maka ia akan berpikir mendua, dan berusaha untuk mencari tambahan penghasilan lain di luar, sehingga menyebabkan ia sering mangkir, sering minta izin keluar.

2. Ada tidaknya keterlaluan pimpinan dalam perusahaan.
Keteladanan pimpinan sangat penting sekali, karena dalam lingkungan perusahaan, semua karyawan akan selalu memerhatikan bagaimana pimpinan dapat menegakkan disiplin dirinya dan bagaimana ia dapat mengendalikan dirinya dari ucapan, perbuatan, dan sikap yang dapat merugikan aturan disiplin yang sudah ditetapkan. Peranan keteladanan pimpinan sangat berpengaruh besar dalam perusahaan, bahkan sangat dominan dibandingkan dengan semua faktor yang memperngaruhi disiplin dalam perusahaan, karena pimpinan dalam suatu perusahaan masih menjadi panutan para karyawan. Para bawahan akan selalu meniru yang dilihatnya setiap hari.

3. Ada tidaknya aturan pasti yang dapat dijadikan pegangan.

Pembinaan disiplin tidak akan dapat terlaksana dalam perusahaan, bila tidak ada aturan tertulis yang pasti untuk dapat dijadikan pegangan bersama. Disiplin tidak mungkin ditegakkan bila peraturan yang dibuat hanya berdasarkan instruksi lisan yang dapat berubah-ubah sesuai dengan kondisi dan situasi.

4. Keberanian pimpinan dalam mengambil tindakan.

Bila ada seorang karyawan yang melanggar disiplin, maka perlu ada keberanian pimpinan untuk mengambil tindakan yang sesuai dengan tingkat pelanggaran yang dibuatnya. Dengan adanya tindakan terhadap pelanggar disiplin, sesuai dengan sanksi yang ada, maka semua karyawan akan merasa terlindungi, dan dalam hatinya berjanji tidak akan berbuat hal yang serupa.

5. Ada tidaknya pengawasan pimpinan.

Dalam setiap kegiatan yang dilakukan oleh perusahaan perlu ada pengawasan, yang akan mengarahkan para karyawan agar dapat melaksanakan pekerjaan dengan tepat dan sesuai dengan yang telah ditetapkan. Namun sudah menjadi tabiat manusia pula bahwa mereka selalu ingin bebas, tanpa terikat atau diikat oleh peraturan apa pun juga. Dengan adanya pengawasan seperti demikian, maka sedikit banyak par karyawan akan terbiasa melaksanakan disiplin kerja. Mungkin untuk sebagian karyawan yang sudah menyadari arti disiplin, pengawasan seperti ini tidak perlu, tetapi bagi karyawan lainnya, tegaknya disiplin masih perlu agak dipaksakan, agar mereka tidak berbuat semaunya dalam perusahaan.

6. Ada tidaknya perhatian kepada para karyawan. 
Karyawan adalah manusia yang mempunyai perbedaan karakter antara yang satu dengan yang lain. Seorang karyawan tidak hanya puas dengan penerimaan kompensasi yang tinggi, pekerjaan yang menantang, tetapi juga mereka masih membutuhkan perhatian yang besar dari pimpinannya sendiri. Keluhan dan kesulitan mereka ingin didengar, dan dicarikan jalan keluarnya, dan sebagainnya. Pimpinan yang berhasil memberi perhatian yang besar kepada para karyawan akan dapat menciptkan disiplin kerja yang baik.

7. Diciptakan kebiasaan-kebiasaan yang mendukung tegaknya disiplin.

Kebiasaan-kebiasaan positif itu antara lain:

a. Saling menghormati, bila ketemu di lingkungan pekerjaan.

b. Melontarkan pujian sesuai dengan tempat dan waktunya, sehingga para karyawan akan turut merasa bangga dengan pujian tersebut.

c. Sering mengikutsertakan karyawan dalam pertemuan-pertemuan, apalagi pertemuan yang berkaitan dengan nasib dan pekerjaan mereka.

d. Memberi tahu bila ingin meninggalkan tempat kepada rekan sekerja, dengan menginformasikan, kemana dan untuk urusan apa, walaupun kepada bawahan sekalipun.

Absensi atau tidak hadirnya karyawan, oleh Tohadi dalam (Safudin, 2017) ditunjukkan sebabnya antara lain karena karyawan sakit, kesehatan menurun, atau sedang menyelesaikan urusan pribadi. Dalam bentuk pelanggaran disiplin, absensi ini disebabkan oleh rendahnya rasa tanggung jawab karyawan, karena tidak mampu mengontroldiri terhadap acara-acara musiman yang dianggap baik, seperti menikmati libur melampaui liburan yang ditentukan atau pada hari-hari pembukaan acara maupun pertandingan tertentu. Karyawan yang berusia muda banyak yang melakukan perlanggaran ini, demikian juga dengan karyawan baru atau tua, di samping lokasi kerja yang jauh.

\section{Indikator-Indikator Disiplin Kerja}

Indikator disiplin menurut Geroge Straves dan Leonard Sayles yang dikutip oleh Hadikusuma dan Rochmulyati dalam (Setiawan \& Yulianti, 2018) adalah sebagai berikut:

1. Presensi (Kehadiran)

2. Penggunaan Jam Kerja

3. Tanggung Jawab

4. Tingkat Perputaran Pegawai

\section{METODOLOGI PENELITIAN}

Metode penelitian yang digunakan dalam penelitian ini adalah metode penelitian kuantitatif. Dalam penelitian ini menggunakan beberapa metode penelitian untuk mendapatkan data sebagai objek penulisan. Adapun metode penelitian yang digunakan adalah:

1. Data Primer

a. Metode Wawancara

Metode wawancara yaitu teknik pengumpulan data dengan mengajukan pertanyaan kepada pihak-pihak yang berhubungan dengan masalah yang diteliti, guna mendapatkan data-data yang diperlukan.

b. Metode Kuesioner

Metode kuesioner yaitu dengan membuat daftar pertanyaan terlebih dahulu untuk mendapatkan jawaban secara tertulis dari beberapa karyawan yang mewakili objek penelitian, dengan cara mengajukan pertanyaan-pertanyaaan (pertanyaan yang sudah disiapkan secara tertulis dengan alternatif jawaban yang telah disediakan).

2. Data Sekunder atau Studi Kepustakaan

Data sekunder yaitu data yang diperoleh atau dikumpulkan dari sumber-sumber yang ada. Data ini diperoleh dari buku-buku atau laporanlaporan terdahulu yang berkaitan dengan disiplin kerja dan kinerja karyawan.

\section{Populasi dan Sampel}

Penulis melakukan penelitian pada bulan Januari 2020. Dengan pengambilan data yang digunakan penulis selama bulan Oktober dan November 2019 penulis menggunakan metode pengambilan secara acak (simple random sampling) yang dimana seluruh anggota populasi mempunyai kesempatan yang sama untuk dipilih. Dalam penelitian ini penulis menetapkan judul Pengaruh Absensi Fingerprint Terhadap Peningkatan Disiplin Kerja Pegawai Pada Kementerian Komunikasi Dan Informatika dengan jumlah sample 60 responden dari 150 pegawai. Dalam penelitian ini metode pengambilan sample yang penulis gunakan adalah Simple Random Sampling. Simple Random Sampling adalah pengambilan anggota sample dan populasi dilakukan secara acak tanpa memperhatikan strata yang ada dalam populasi itu. Perhitungan yang penulis lakukan dibantu dengan menggunakan program SPSS versi 25. Jumlah tersebut akan dijadikan sebagai populasi dalam penelitian ini. 


\section{Uji Validitas}

Uji validitas adalah uji yang digunakan untuk menunjukkan sejauh mana alat ukur yang digunakan dalam suatu mengukur apa yang diukur. Uji validitas digunakan untuk mengukur sah, atau valid tidaknya suatu kuesioner. Suatu kuesioner dikatakan valid jika pertanyaan pada kuesioner mampu untuk mengungkapkan sesuatu yang akan diukur oleh kuesioner tersebut.

2. Uji Reliabilitas

Reliabilitas, atau keandalan, adalah konsistensi dari serangkaian pengukuran atau serangkaian alat ukur. Hal tersebut bisa berupa pengukuran dari alat ukur yang sama (tes dengan tes ulang) akan memberikan hasil yang sama, atau untuk pengukuran yang lebih subjektif, apakah dua orang penilai memberikan skor yang mirip (reliabilitas antar penilai). Reliabilitas tidak sama dengan validitas. Artinya pengukuran yang dapat diandalkan akan mengukur secara konsisten, tapi belum tentu mengukur apa yang seharusnya diukur.

\section{Uji Koefisien Korelasi}

Koefisien korelasi adalah nilai yang menunjukan kuat / tidaknya hubungan linier antar dua variabel. Koefisien korelasi biasa dilambangkan dengan huruf $r$ dimana nilai $r$ dapat bervariasi dari -1 sampai +1 . Nilai $r$ yang mendekati -1 atau +1 menunjukan hubungan yang kuat antara dua variabel tersebut dan nilai $r$ yang mendekati 0 mengindikasikan lemahnya hubungan antara dua variabel tersebut. Sedangkan tanda + (positif) dan - (negatif) memberikan informasi mengenai arah hubungan antara dua variabel tersebut. Jika bernilai + (positif) maka kedua variabel tersebut memiliki hubungan yang searah. Dalam arti lain peningkatan $X$ akan bersamaan dengan peningkatan $Y$ dan begitu juga sebaliknya. Jika bernilai - (negatif) artinya korelasi antara kedua variabel tersebut bersifat berlawanan. Peningkatan nilai $X$ akan dibarengi dengan penurunan Y. Koefisien korelasi pearson atau Product Moment Coefficient of Correlation adalah nilai yang menunjukan keeratan hubungan linier dua variabel dengan skala data interval atau rasio.
4. Uji Koefisien Determinasi

Koefisien determinasi pada regresi linear sering diartikan sebagai seberapa besar kemampuan semua variabel bebas dalam menjelaskan varians dari variabel terikatnya. Secara sederhana koefisien determinasi dihitung dengan mengkuadratkan Koefisien Korelasi (R).

5. Uji Persamaan Regresi

Uji Persamaan Regresi merupakan suatu alat ukur yang digunakan untuk mengukur ada atau tidaknya korelasi antar variabel.

\section{HASIL DAN PEMBAHASAN}

Adapun hasil penelitian yang penulis peroleh adalah sebegai berikut

\section{Uji Validitas}

Uji validitas sering digunakan untuk mengukur ketepatan suatu item dalam kuesioner atau skala, apakah item-item pada kuesioner tersebut sudah tepat dalam mengukur apa yang ingin diukur. $\mathrm{Uji}$ validitas dilakukan dengan menghitung korelasi antar skor atau butir pertanyaan dengan skor konstruk atau variabel.

Hal ini dapat dilakukan dengan cara uji signifikansi yang membandingkan $r$ hitung dengan $r$ tabel untuk degree of freedom $(\mathrm{df})=\mathrm{n}-\mathrm{k}$. Dalam hal ini $\mathrm{n}$ adalah jumlah sampel dan $\mathrm{k}$ adalah jumlah konstruk. Apabila $r$ hitung lebih besar dari $r$ tabel maka instrumen atau item-item pertanyaan berkorelasi signifikan terhadap skor total (dinyatakan valid). Sebaliknya, jika $r$ hitung lebih kecil dari $r$ tabel maka instrumen atau pertanyaan tidak berkorelasi signifikan terhadap skor total (dinyatakan tidak valid). Nilai $r$ tabel dapat dilihat pada tabel $\mathrm{r}$ dengan taraf signifikan $10 \%$ atau setara dengan 0,1. Maka dapat dijelaskan sebagai berikut:

$$
\mathrm{Df}=60-2=58 \text {. Jadi nilai } \mathrm{r} \text { tabel }=0.2994 \text {. }
$$

Dari hasil perhitungan menggunakan software SPSS maka diperoleh data $r$ hitung pada variabel $\mathrm{X}$ dan $\mathrm{Y}$ sebagai berikut: 
Tabel 1. Hasil Validitas Variabel X dan Y

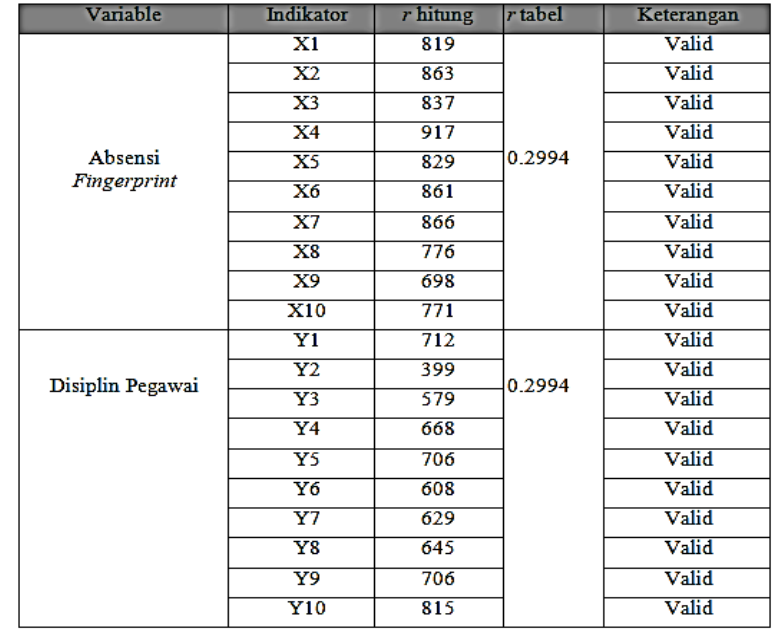

Sumber : Data yang diolah SPSS 25, 2019

Dilihat dari tabel diatas kesimpulannya semua data valid. Berdasarkan hasill perhitungan pada tabel diatas dapat disimpulkan bahwa semua item pernyataan yang terdapat dalam kuesioner penelitiaabsensi fingerprint dan disiplin kerja pada Kementerian Komunikasi dan Informatika adalah valid, sesuai dengan kriteria uji validitas $r$ hitung lebih besar dari 0,2144 .

\section{Uji Reliabilitas}

Uji Reliabilitas dilakukan menggunakan Cronbach Alpha. Untuk menentukan reliabel atau tidaknya instrument dapat diinterpretasikan dengan batasan yang lebih dari 0,6 adalah cukup reliable, sedangkan batasan 0,8 adalah reliable dan diatas 0,8 adalah sangat reliable.

Berikut ini adalah hasil perhitungan reliabilitas dapat dilihat dalam tabel berikut:

Tabel 2. Hasil Reliabilitas X

\begin{tabular}{|r|r|r|}
\hline \multicolumn{3}{|c|}{ Reliability Statistics } \\
\hline & $\begin{array}{c}\text { Cronbach's } \\
\text { Alpha Based on } \\
\text { Standardized } \\
\text { Alpha } \\
\text { Items }\end{array}$ & \\
\hline 960 & & $\begin{array}{c}\text { N of } \\
\text { Items }\end{array}$ \\
\hline & .960 & 10 \\
\hline
\end{tabular}

Sumber: Perhitungan SPSS 25, 2019

Tabel 3. Hasil Reliabilitas Y

\begin{tabular}{|c|c|c|}
\hline \multicolumn{2}{|c|}{ Reliability Statistics } \\
\hline & $\begin{array}{c}\text { Cronbach's } \\
\text { Alpha Based on } \\
\text { Standardized } \\
\text { Cronbach's } \\
\text { Alpha }\end{array}$ & \\
\hline Items & N of Items \\
\hline
\end{tabular}

Sumber: Perhitungan SPSS 25, 2019 
Berdasarkan tabel diatas, dapat diketahui bahwa semua variabel $\mathrm{X}$ dan $\mathrm{Y}$ memiliki nilai Cronbach's Alpha lebih besar dari 0,6 ( 0,960 dan
$0,898>0,6$ ). Dengan demikian semua variabel dapat dikatakan reliabel. Hal tersebut dapat dilihat pada tabel sebagai berikut:

Tabel 4. Rekap Hasil Uji Reliabilitas X dan Y

\begin{tabular}{|c|c|l|}
\hline Variabel & Cronbach Alfa & Keterangan \\
\hline $\mathrm{X}$ & 0,960 & $\begin{array}{l}\text { Sangat } \\
\text { Reliabel }\end{array}$ \\
\hline $\mathrm{Y}$ & 0,898 & $\begin{array}{l}\text { Sangat } \\
\text { Reliabel }\end{array}$ \\
\hline
\end{tabular}

Sumber: Perhitungan SPSS 25, 2019

Sehingga dapat disimpulkan seluruh butir pertanyaan tentang Absensi Fingerprint dan Disiplin Kerja Pegawai adalah sangat Reliabel.

\section{Uji Koefisien Korelasi}

Analisis ini digunakan untuk mengetahui seberapa besar hubungan dan interprestasi antara variable absensi fingerprint (variable $\mathrm{X}$ ) terhadap variable disiplin kerja (variable Y) pada Kementerian Komunikasi dan Informatika yang dilihat dari hasil perhitungan menggunakan Program SPSS 25.

Berikut ini adalah data hasil perhitungan menggunakan program SPSS 25 dapat dilihat dalam tabel berikut:

Tabel 5. Hasil Koefisien Korelasi

\begin{tabular}{|c|c|c|c|}
\hline \multicolumn{4}{|c|}{ Correlations } \\
\hline & & $\mathrm{X}$ & $\mathrm{Y}$ \\
\hline \multirow[t]{3}{*}{$\mathrm{X}$} & Pearson Correlation & 1 & $.773^{* *}$ \\
\hline & Sig. (2-tailed) & & .000 \\
\hline & $\mathrm{N}$ & 60 & 60 \\
\hline \multirow[t]{3}{*}{ Y } & Pearson Correlation & $.773^{* *}$ & 1 \\
\hline & Sig. (2-tailed) & .000 & \\
\hline & $\mathrm{N}$ & 60 & 60 \\
\hline & lation is significan & 0.011 & \\
\hline
\end{tabular}

Sumber : Perhitungan SPSS 25, 2019

Dari tabel diatas maka dapat disimpulkan bahwa nilai korelasi (hubungan) antara Absensi Fingerprint dengan Disiplin Kerja sebesar 0,773. Berdasarkan tabel pedoman interprestasi koefisien korelasi, nilai tersebut termasuk dalam kategori kuat. Sehingga bisa disimpulkan bahwa terdapat hubungan yang positif sebesar 0,773 antara absensi fingerprint terhadap disiplin kerja.

\section{Uji Koefisien Determinasi}

Setelah ditemukan hasil koefisien korelasi kemudian langkah selanjutnya adalah mencari koefisien determinasi. Uji Koefisien Determinasi digunakan untu mengetahui seberapa besar pengaruh Disiplin Kerja terhadap Kinerja Pegawai. Berdasarkan perhitungan koefisiensi determinasi dengan menggunakan SPSS versi 25 adalah sebagai berikut. 
Tabel 6. Hasil Koefisien Determinasi

\begin{tabular}{|c|c|c|c|c|}
\hline \multicolumn{5}{|c|}{$\begin{array}{c}\text { Model } \\
\text { Summary }\end{array}$} \\
\hline Model & $\mathrm{R}$ & $\begin{array}{l}\mathrm{R} \\
\text { Square }\end{array}$ & $\begin{array}{l}\text { Adjuste } \\
\text { d R } \\
\text { Square }\end{array}$ & $\begin{array}{l}\text { Std. Error of } \\
\text { the } \\
\text { Estimate }\end{array}$ \\
\hline 1 & $\begin{array}{l}.77 \\
3^{\mathrm{a}}\end{array}$ & $\begin{array}{l}.59 \\
7\end{array}$ & .590 & $\begin{array}{l}5.3 \\
03\end{array}$ \\
\hline
\end{tabular}

Sumber: Perhitungan SPSS 25, 2019

Berdasarkan tabel di atas, diketahui nilai koefisien determinasi atau $\mathrm{R}$ Square adalah sebesar 0,597. Nilai $R$ Square 0,597 ini berasal dari pengkuadratan nilai koefisien korelasi atau "R", yaitu $0,773 \times 0,773=0,597$. Besarnya angka koefisien determinasi (R Square) adalah 0,597 atau sama dengan 59,7\%. Angka tersebut mengandung arti bahwa variable disiplin kerja (X) terhadap variable kinerja pegawai (Y) berpengaruh sebesar $59,7 \%$. Sedangkan sisanya $(100 \%-59,7 \%=$ $40,3 \%$ ) dipengaruhi oleh variable lain di luar persamaan regresi ini atau variable yang tidak diteliti.

\section{Uji Persamaan Regresi}

Regresi sederhana digunakan untuk melakukan prediksi seberapa tinggi nilai variable dependen bila nilai variable indipenden dimanipulasi (dirubah-rubah). Berdasarkan hasil analisis dengan menggunakan program SPSS 25, maka diperoleh hasil regresi antara absensi fingerprint terhadap disiplin kerja sebagai berikut.

Tabel 7. Hasil Analisis Regresi Absensi Fingerprint Terhadap Disiplin

\begin{tabular}{|c|c|c|c|c|c|c|}
\hline \multicolumn{7}{|c|}{ Coefficients $^{\mathbf{a}}$} \\
\hline \multirow{2}{*}{\multicolumn{2}{|c|}{ Model }} & \multicolumn{2}{|c|}{$\begin{array}{l}\text { Unstandardized } \\
\text { Coefficients }\end{array}$} & $\begin{array}{l}\text { Standardize } \\
\mathrm{d} \\
\text { Coefficient } \\
\mathrm{s}\end{array}$ & \multirow[b]{2}{*}{$\mathrm{T}$} & \multirow[b]{2}{*}{ Sig. } \\
\hline & & $\mathrm{B}$ & Std. Error & Beta & & \\
\hline \multirow[t]{2}{*}{1} & (Constant) & -1.625 & 4.626 & & -.351 & .727 \\
\hline & $\mathrm{Y}$ & 1.010 & .109 & .773 & 9.272 & .000 \\
\hline & ent Vari & & & & & \\
\hline
\end{tabular}

Sumber: Perhitungan SPSS 25, 2019

Berdasarkan tabel perhitungan SPSS diatas, dapat diperoleh persamaan yaitu :

$$
Y=-1,625+1,010 X
$$

Dari persamaan fungsi diatas, dapat diinterprestasikan bahwa bila absensi fingerprint bersifat konstan atau bernilai 0 (nol) maka Y (disiplin kerja) adalah sebesar 1,010. Koefisien regresi X sebesar -1,625 menyatakan bahwa setiap penambahan (karena tanda positif) 1 kali untuk disiplin kerja akan meningkat kinerja pegawai sebesar 1,010. Dan sebaliknya, jika disiplin mengalami penurunan 1 kali maka kinerja diprediksi mengalami penurunan sebesar 1,010. Jadi arah hubungan absensi fingerprint terhadap disiplin kerja adalah positif antara absensi fingerprint dengan disiplin kerja, semakin tinggi absensi fingerprint maka semakin meningkat pula disiplin kerja. Jadi dapat disimpulkan bahwa absensi fingerprint berpengaruh terhadap disiplin kerja pada Kementerian Komunikasi dan Informatika.

Berdasarkan tabel perhitungan SPSS 25 di atas, dapat diperoleh persasmaan yaitu: 
$Y=a+b x a=-1,625 Y b=1,010 X$

Dimana :
$\mathrm{Y}=$ Disiplin Kerja

$\mathrm{X}=$ Absensi Fingerprint

Tabel 8. Hasil Nilai Regresi $\mathrm{Y}=\mathrm{a}+\mathrm{bx}$

\begin{tabular}{|c|c|c|c|c|c|c|c|}
\hline No & $X$ & $\begin{array}{c}Y=a+b \\
x\end{array}$ & $\begin{array}{c}\text { Y } \\
\text { Prediksi }\end{array}$ & No & $X$ & $\begin{array}{c}Y=a+b \\
x\end{array}$ & $\begin{array}{c}\mathrm{Y} \\
\text { Prediksi }\end{array}$ \\
\hline 1 & 22 & 22,22 & 24 & 31 & 17 & 17,17 & 19 \\
\hline 2 & 45 & 45,45 & 47 & 32 & 45 & 45,45 & 47 \\
\hline 3 & 46 & 46,46 & 48 & 33 & 44 & 44,44 & 46 \\
\hline 4 & 34 & 34,34 & 36 & 34 & 26 & 26,26 & 28 \\
\hline 5 & 45 & 45,45 & 47 & 35 & 17 & 17,17 & 19 \\
\hline 6 & 44 & 44,44 & 46 & 36 & 44 & 44,44 & 46 \\
\hline 7 & 44 & 44,44 & 46 & 37 & 44 & 44,44 & 46 \\
\hline 8 & 43 & 43,43 & 45 & 38 & 43 & 43,43 & 45 \\
\hline 9 & 50 & 50,5 & 52 & 39 & 45 & 45,45 & 47 \\
\hline 10 & 29 & 29,29 & 31 & 40 & 48 & 48,48 & 50 \\
\hline 11 & 22 & 22,22 & 24 & 41 & 45 & 45,45 & 47 \\
\hline 12 & 40 & 40,4 & 42 & 42 & 41 & 41,41 & 43 \\
\hline 13 & 37 & 37,37 & 39 & 43 & 43 & 43,43 & 45 \\
\hline 14 & 47 & 47,47 & 49 & 44 & 46 & 46,46 & 48 \\
\hline 15 & 43 & 43,43 & 45 & 45 & 43 & 43,43 & 45 \\
\hline 16 & 41 & 41,41 & 43 & 46 & 46 & 46,46 & 48 \\
\hline 17 & 43 & 43,43 & 45 & 47 & 40 & 40,4 & 42 \\
\hline 18 & 46 & 46,46 & 48 & 48 & 33 & 33,33 & 35 \\
\hline 19 & 43 & 43,43 & 45 & 49 & 45 & 45,45 & 47 \\
\hline 20 & 46 & 46,46 & 48 & 50 & 46 & 46,46 & 48 \\
\hline 21 & 41 & 41,41 & 43 & 51 & 44 & 44,44 & 46 \\
\hline 22 & 50 & 50,5 & 52 & 52 & 45 & 45,45 & 47 \\
\hline 23 & 47 & 47,47 & 49 & 53 & 17 & 17,17 & 19 \\
\hline 24 & 46 & 46,46 & 48 & 54 & 40 & 40,4 & 42 \\
\hline 25 & 50 & 50,5 & 52 & 55 & 40 & 40,4 & 42 \\
\hline 26 & 40 & 40,4 & 42 & 56 & 45 & 45,45 & 47 \\
\hline 27 & 43 & 43,43 & 45 & 57 & 46 & 46,46 & 48 \\
\hline 28 & 43 & 43,43 & 45 & 58 & 26 & 26,26 & 28 \\
\hline 29 & 40 & 40,4 & 42 & 59 & 50 & 50,5 & 52 \\
\hline 30 & 40 & 40,4 & 42 & 60 & 44 & 44,44 & 46 \\
\hline
\end{tabular}

Sumber: Perhitungan SPSS 25, 2019

Konstan (a) $=-1,625$ menyatakan jika absensi fingerprint $(\mathrm{X})$ nilainya adalah 0 maka disiplin kerja $(Y)$ nilainya negatif $-1,625$. Koefisien regresi variable absensi fingerprint (X) sebesar 351 , artinya jika absensi fingerprint mengalami peningkatan maka disiplin kerja (Y) akan mengalami peningkatan juga sebesar -351 . Koefisien bernilai positif artinya terjadi hubungan positif antara absensi fingerprint dengan disiplin kerja, semakin tinggi tingkat absensi maka semakin tinggi juga disiplin kerja.

\section{KESIMPULAN DAN SARAN}

\section{Kesimpulan}

Berdasarkan hasil analisis dan pembahasan yang telah dikemukakan pada bab sebelumnya. 
Maka penulis akan memberi kesimpulan yang diambil dari hasil penelitian mengenai Pengaruh Absensi Fingerprint Terhadap Peningkatan Disiplin Kerja Pegawai Pada Kementerian Komunikasi dan Informatika Jakarta, Sebagai berikut:

1. Absensi fingerprint terhadap disiplin kerja memiliki hubungan yang kuat dan positif hal tersebut ditunjukkan berdasarkan perhitungan koefisien korelasi dengan menggunakan SPSS dengan hasil sebesar 0,773 dan nilai tersebut berada dalam ketegori kuat.

2. Berdasarkan perhitungan Koefisien Determinasi yang di sesuaikan (R Square) adalah sebesar 0,579 artinya $59,7 \%$ variabel absensi fingerprint dapat dipengaruhi oleh variabel disiplin kerja. Sedangkan sisanya sebesar 40,3\% dipengaruhi oleh faktor lain.

3. Dari hasil persamaan regresi dapat diketahui hubungan antara Disiplin dengan Kinerja $\mathrm{Y}=$ $-1,625+1,010 \mathrm{X}$. Persamaan ini menunjukkan, bila absensi fingerprint bersifat konstan atau bernilai 0 (nol) maka Y (disiplin kerja) sebesar 7,428. Koefisien regresi $X$ sebesar 1,010 menyatakan bahwa setiap penambahan 1 kali absensi fingerprint akan meningkatkan disiplin kerja sebesar 1,010 dan sebaliknya, jika absensi fingerprint mengalami penurunan 1 kali maka disiplin kerja diprediksi mengalami penurunan sebesar 1,010. Jadi arah hubungan absensi fingerprint dengan disiplin kerja adalah positif artinya searah.

\section{Saran}

Berdasarkan hasil penelitian yang dilakukan oleh penulis terdapat beberapa saran yang dijadikan sebagai masukan serta dapat memberikan manfaat bagi pegawai divisi kepegawaian pada Kementerian Komunikasi dan Informatika Jakarta. Berikut adalah saran yang dapat dipertimbangkan antara lain :

1. Perlu ditingkatkannya sosialisasi kepada pegawai agar pegawai terus dapat menggunakan absensi fingerprint dan tidak asing lagi dengan alat tersebut, upaya ini akan menjadi faktor yang penting dalam meningkatkan efektivitas penerapan absensi fingerprint guna meningkatkan disiplin kehadiran pegawai.

2. Pimpinan hendaknya lebih mengawai sistem yang sedang diterapkan, karena tanpa pengawasan semua tidak akan berjalan baik dan pimpinan juga harus tegas dalam memberikan sanksi agar semua yang melanggar peraturan jera dan tidak ada lagi yang melanggar peraturan yang artinya kedisiplinan pegawai akan tercipta.

3. Pimpinan sebagai panutan dan contoh bagi pegawai-pegawainya harus lebih memberikan contoh yang baik dan membimbing para pegawai dalam mengerjakan tugas-tugasnya.

\section{DAFTAR PUSTAKA}

Dalle, J., \& Bakeri, M. (2019). Pengaruh Fingerprint Terhadap Jam Kerja Lembur di Perusahaan PT . Jasapower Indonesia. 3, 215.

Erlangga, C. Y. (2017). Pengaruh Gaya Kepemimpinan, Motivasi Dan Disiplin Kerja Terhadap Kinerja Karyawan (Studi Kasus Ombudsman Republik Indonesia).

Jurnal Komunikasi, 8(2). Retrieved from http://ejournal.bsi.ac.id/ejurnal/index.php/jk om/article/view/2530

Hasibuan, M. (2017). Manajemen Sumber Daya Manusia. Jakarta: Bumi Aksara.

Hasiolan, L. B., Fathoni, A., \& Kota, D. (2016). Pengaruh Mekanisme Finger Print , Prosedur Finger Print, Pencapaian Target Finger Print Terhadap Kedisiplinan Pegawai Di Sekretariat Dewan Perwakilan Rakyat Daerah. Journal of Management, 2(2). Retrieved from https://jurnal.unpand.ac.id/index.php/MS/art icle/viewFile/595/579

Kristin, L. S. (2016). Pengaruh Penerapan Presensi Sidik Jari ( Fingerprint ) terhadap Kinerja Guru Melalui Motivasi Kerja di SMA Negeri 5 Malang. 170- 177.

Rahman, A., \& Esterina, S. M. (2018). Pengaruh Gaya Kepemimpinan Terhadap Kinerja Pegawai. SNIT 2018, 1(1), 28-34.

Safudin, M. (2017). Pengaruh Penerapan Absensi Online Terhadap Disiplin Pada Karyawan. IJSE - Indonesian Journal on Software Engineering, 3(2), 105-108. Retrieved from https://ejournal.bsi.ac.id/ejurnal/index.php/ij se/article/view/3361

Setiawan, D. R., \& Yulianti, Y. (2018). Pengaruh Absensi Fingerprint Terhadap Disiplin Kerja Karyawan Pada Pt. Sanbio Laboratories Gunung Putri Kabupaten Bogor. Majalah Ilmiah Bijak, 14(1), 70-81. https://doi.org/10.31334/bijak.v14i1.61

Sugiyono, 2017, Metode Penelitian ; Kuantitatif Kualitatif dan R\&D, Bandung, Alfabeta

Sutrisno, E. (2017). Manajemen Sumber Daya Manusia (9th ed.). Jakarta: Kencana. 
Suwandi, M. (2018). Pengaruh Penerapan Absensi Fingerprint Terhadap Disiplin Kerja Pada PT . TELKOM Indonesia Jakarta. 1(2), 110.
Yuliantari, K., \& Wiwin, W. (2018). Pengaruh Citra Merek Terhadap Keputusan Pembelian Konsumen tukangroti.com di bekasi. Jurnal Akrab Juara, 3(4), 9-21. 